\title{
Next generation immune-checkpoints for cancer therapy
}

\author{
Chiara Donini $^{1 \#}$, Lorenzo D'Ambrosio ${ }^{1,2 \#}$, Giovanni Grignani ${ }^{1,2}$, Massimo Aglietta $^{1,2,3}$, Dario Sangiolo ${ }^{1,3}$ \\ ${ }^{1}$ Department of Oncology, University of Torino, Torino, Italy; ${ }^{2}$ Division of Medical Oncology, Sarcoma Unit, ${ }^{3}$ Division of Medical Oncology, \\ Experimental Cell Therapy, Candiolo Cancer Institute FPO-IRCCS, Candiolo, Torino, Italy \\ Contributions: (I) Conception and design: All authors; (II) Administrative support: None; (III) Provision of study materials or patients: None; (IV) \\ Collection and assembly of data: None; (V) Data analysis and interpretation: None; (VI) Manuscript writing: All authors; (VII) Final approval of \\ manuscript: All authors. \\ \#These authors contributed equally to this work. \\ Correspondence to: Dario Sangiolo, MD, PhD. Department of Oncology, University of Torino, Provinciale 142 - 10060 Candiolo, Torino, Italy. \\ Email: dario.sangiolo@ircc.it.
}

\begin{abstract}
The discovery and clinical application of immune-checkpoint inhibitors has dramatically improved the treatments, outcomes and therapeutic concepts in multiple tumor settings. This breakthrough was mainly based on monoclonal antibodies blocking the inhibitory molecule CTLA-4 and or the PD-1/PDL1 axis, with the aim of counteracting major tumor immune evasion mechanisms. Even acknowledging these important successes, not all the patients benefit from these treatments. Translational and clinical research efforts are ongoing to explore the potentialities of a new generation of immune-modulatory molecules to extend current clinical applications and contrast the unsolved issues of resistance and disease relapse that still affects a considerable rate of patients. New immune-checkpoints, with either stimulatory or inhibitory functions are emerging with key roles in regulating $\mathrm{T}$ cell response but also affecting other crucial effectors belonging to the innate immune response (e.g., natural killer). Their therapeutic exploitation, either alone or in strategical combinations, is providing important preclinical results, holding promises currently explored in initial clinical trials. The first results point toward favorable safety profiles with selective hints of activity in challenging settings. Important issues regarding the dose, schedule and rational combinations remain open and data from the clinical studies are needed. Here we provide an overview of the main emerging stimulatory or inhibitory immune-checkpoints exploitable in cancer treatment, briefly reporting their biological function, preclinical activity and preliminary clinical data.
\end{abstract}

Keywords: Checkpoints; immunotherapy; lymphocytes; solid tumors

Submitted Feb 07, 2018. Accepted for publication Feb 12, 2018.

doi: $10.21037 /$ jtd.2018.02.79

View this article at: http://dx.doi.org/10.21037/jtd.2018.02.79

\section{Introduction}

In the last decade, cancer immunotherapy has positively revolutionized outcomes and basic concepts of oncological treatments. Most of such breakthroughs are due to the discovery and therapeutic modulation of key immuneregulatory molecules (checkpoints) at the interface between immune effectors and tumor microenvironment (1). Monoclonal antibodies blocking the inhibitory checkpoints CTLA-4 and PD-1 (or the corresponding ligand PD-L1) were the first to enter the clinical arena with impressive results, initially confined to metastatic melanoma and now progressively extending to multiple tumor settings like lung, kidney, bladder, head and neck cancers (2-8). The underlying biological concept exploited by these treatments is to unleash a potentially effective antitumor adaptive immune response that has been inhibited by tumor adaptive-resistance expedients. Even considering the important clinical successes obtained by the "first generation" of checkpoint inhibitors (CI), a relevant rate of patients has unsatisfactory responses or relapses following an initial clinical benefit. A profound, progressive 
exploration of the complex regulatory interactions among the heterogeneous protagonists of the anticancer immune response is absolutely necessary to understand issues of resistance/relapse and plan rational innovative counteractive strategies. It is now clear that multiple modulatory checkpoints, either inhibitory of stimulatory, play important or situational roles providing multiple new appealing targets for innovative modulatory/therapeutic strategies $(9,10)$. Their initial exploration is starting in clinical trials with promising initial results and with possibly exciting perspectives offered by combinatorial opportunities. A summary of the main emerging immune-checkpoints with their functional role is reported in Figure 1.

Here we review the main "new potential targets" for immunotherapy, focusing on emerging regulatory molecules that may be involved at different levels of the complex antitumor immune response, either with "positive" or "negative" functions. We aim to provide an overview with insights in their biological role, evidence of function and perspective clinical exploitation.

\section{Stimulatory checkpoints}

Beside the well-known negative modulatory axes given by CTLA-4/B7 and PD-1/PD-L1, the induction of effective adaptive and innate immune response is regulated by a panel of activatory signals. They are mainly mediated by costimulatory molecules that are often transitorily expressed following the first T-cell receptor (TCR) activation. They are usually either members of immunoglobulin superfamily or tumor necrosis factor (TNF) receptors (TNFR). The discovery of such co-stimulatory modulators has prompted the preclinical and clinical testing of agonistic antibodies that hold promises in several tumor settings, especially if combined with a simultaneous blocking of inhibitory checkpoints.

\section{ICOS}

ICOS is a member of the CD28 family of B7 binding proteins. It is relatively low expressed by naïve unstimulated $\mathrm{T}$ lymphocytes, while its expression is enhanced upon $\mathrm{T}$ cell activation. The designated ligand (ICOS-L; B7-H2) is mainly expressed by dendritic cells and macrophages but also a direct expression by tumors has been reported (11-19). The binding of ICOS with such ligand determines T cell activation, mostly resulting in the secretion of various types of cytokines than in the induction of a direct cytotoxic activity. The secreted cytokines are mostly of proinflammatory Th1 type despite also regulatory Th2 types are produced $(9,20,21)$.

The expression of ICOS-positive lymphocytes and ICOS-L has been reported in various tumor settings and considered with alternate prognostic valence (9,22-24). In a recent report, its expression at tumor sites in colorectal carcinoma (CRC) patients was strongly correlated with favorable prognosis (19) while other studies in breast cancer settings suggested a negative correlation with the outcome $(9,25,26)$. The activity of ICOS appears to be linked to T cell activation following CTLA-4 blockage. ICOS stimulation may significantly enhance the immune-stimulatory effect of CTLA4 blocking antibodies that, conversely, is impaired in ICOS knock-out models $(27,28)$. A positive synergism was reported also following anti-PD-1 treatment $(9,29)$.

Altogether current evidences support ICOS as a relevant and potentially exploitable marker of $\mathrm{T}$ cell activation. Its expression by CD4 and CD8 T lymphocytes, following treatments with checkpoint inhibitors, may be indicative of the intended re-activation of anticancer immune response. It seems to be associated with clinical responses and correlates with prognosis $(23,24,29-32)$. Currently available evidences support a foreseeable therapeutic scenario wherein ICOS stimulation may be explored more in association with antiCTLA4 or anti-PD-1 than as single treatment.

\section{OX40}

OX40 is a type 1 transmembrane receptor, originally described to be expressed by activated CD4 T cells, subsequently demonstrated on CD8 but also natural killer (NK) cells and neutrophils (33-37). Its regulatory function goes beyond the adaptive immunity and may also involve innate response. Its ligand (OX40-L) is mainly expressed by antigen-presenting cells (APCs) but may also be found in other circulating cells (NK, Mast $\mathrm{T}$, activated lymphocytes) or other tissues like muscles or vascular endothelium $(38,39)$. OX40 expression is transiently enhanced following TCR binding and upon ligand binding enhances $\mathrm{T}$ cell activation, with production of cytokine sustaining lymphocyte survival, proliferation and sustained memory $(40,41)$. The increased IFN- $\gamma$ levels, beside sustaining Th1 type responses may also favor PD-L1 expression with negative regulatory implications laying basis for synergism with checkpoint inhibitors $(36,42)$. Notably, OX40 is also expressed by regulatory $\mathrm{T}$ cell (Treg), but in this context the activity of OX40 is mainly inhibitory, either resulting 


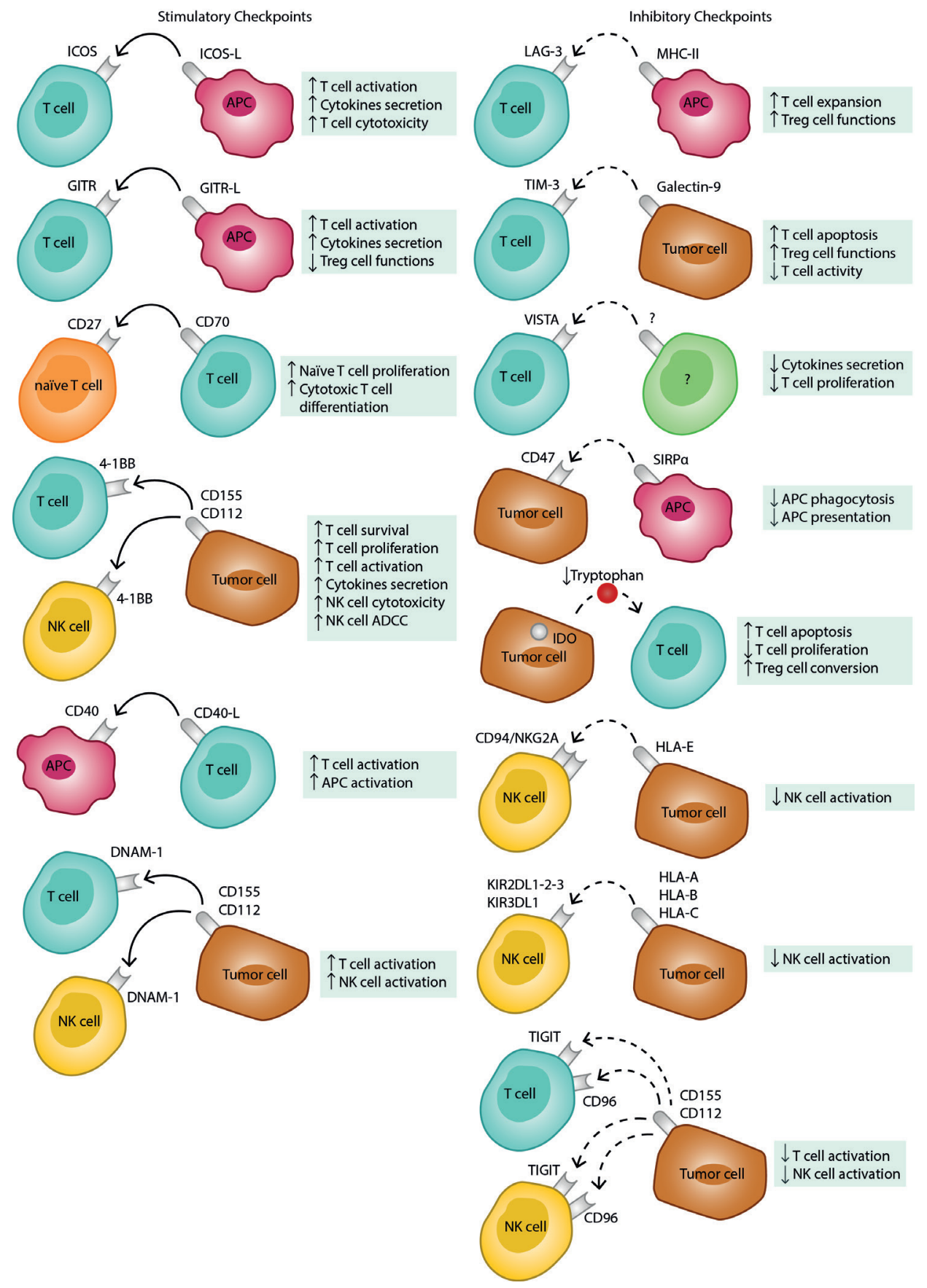

Figure 1 Main stimulatory and inhibitory checkpoints, immune cells involved and principal regulatory function. Stimulatory interactions are marked by solid arrows while inhibitory interactions are marked by dashed arrows. Up arrows highlight function increase while down arrows highlight function decrease. GITR, glucocorticoid-induced TNF receptor-related gene; TNF, tumor necrosis factor; GITR-L, glucocorticoid-induced TNF receptor-related gene ligand; LAG-3, lymphocyte activation gene-3; MHC, major histocompatibility complex; HLA, human leucocyte antigen; TIM-3, T-cell immunoglobulin and mucin domain 3; ICOS, inducible T-cell costimulator; ICOS-L, inducible T-cell costimulator ligand; TIGIT, T cell Immunoglobulin and ITIM domain; VISTA, V-domain Ig suppressor of T-cell activation; IDO, indoleamine-2,3-dioxygenase; KIR, killer immunoglobulin-like receptor; SIRP $\alpha$, signal-regulatory protein alpha; DNAM1, DNAX Accessory Molecule-1; NK, natural killer; APC, antigen-presenting cell; Tregs, regulatory T cells; ADCC, antibody dependent cellular cytotoxicity. 
in their functional inhibition or direct depletion (43). The role of OX40 in Tregs is not however completely clear and, according to the context and cytokine environment, stimulating activities have also been reported (44). Early preclinical evidence showed that OX40 stimulation could induce effective antitumor responses against immunogenic models including sarcoma, melanoma and breast cancer (45-47). Its activity as monotherapy was less effective against poorly immunogenic models (48), supporting the concept that OX40 stimulation could be better exploited in association with other therapeutic strategies that may concurrently contribute to or benefit from Tregs depletion $(49,50)$. The first phase I clinical trial reported an excellent safety profile, with promising but not impressive results in terms of tumor responses (51). Given the murine origin of the agonistic $\mathrm{Ab}$ against $\mathrm{OX} 40$, an intense immunization was observed in most of the first treated patients (51). Several trials are currently exploring humanized forms of anti-OX40 agonists against various types of cancers, in particular exploiting potentially powerful synergism with immune-stimulating agents like checkpoint inhibitors (52).

\section{Glucocorticoid-induced TNF receptor-related gene (GITR)}

GITR is a member of TNFR family. It is constitutively found in Tregs $(53,54)$ and intensely expressed by CD 8 and CD4 lymphocytes upon TCR activation $(55,56)$. GITR has also described in elements of the innate immune system like NK, eosinophils and macrophages (57). Similarly to OX40, the ligand for GITR (GITR-L) is mainly expressed by APC but have been also reported in vessel endothelial cells (58). GITR stimulation is capable of activating $\mathrm{T}$ effector cells (59), by upregulation of IL2R $\alpha$ and production of IL-2 and IFN- $\gamma(56,60)$, while inhibiting Tregs functions with FOXP3 suppression (61-63). Early preclinical data in several solid tumor models confirmed the therapeutic antitumor potential of GITR stimulation, especially in combination with other immune-modulatory agents (64-71). Notably, the beneficial effect of GITR agonists included also poorly immunogenic models that were limitedly affected by the activation of other stimulatory pathways like that of OX40 (65-71). A first clinical phase I experience with humanized GITR agonist confirmed the optimal safety profile, with only limited responses as single agent (10). Anyway the clinical exploration was warranted and clinical trial are currently ongoing, focusing on combinatorial approaches with other strategies like checkpoint inhibitors (59).

\section{4-1BB (CD137)}

CD137 is an inducible co-stimulatory cell-surface glycoprotein, member of TNFR proteins (72). It is expressed by various types of immune cells like activated $\mathrm{T}$ lymphocytes $\left(\mathrm{CD}^{+}\right.$and $\left.\mathrm{CD} 8^{+}\right), \mathrm{NK}$, macrophages, B cells $(73,74)$. Following the TCR engagement, its expression supports $\mathrm{T}$ cell proliferation, activation, survival and IL-2 production (75). The only ligand so far identified is a member of TNF family (76). Notably, CD137 can potentiate NK cell activation following the triggering of their FC receptor (77). The agonistic stimulation could mediate effective antitumor response in murine models, both by T cell activation (78) and NK antibody dependent cellular cytotoxicity (ADCC) in association with antitumor monoclonal antibodies (79).

Such parallel activity involving the innate arm of the immune response may explain the apparent superior antitumor activity of monotherapy with CD137 agonists compared with similar stimulation of other co-stimulatory molecules described above. Preclinical models are also supporting a synergistic activity with anti-PD-1 and antiCTLA-4 checkpoint inhibitors (80).

Clinical trials are currently exploring the activity of a humanized anti-CD137 agonistic antibody in combination with anti-CD20 (Rituximab) against B cell lymphoma and, with checkpoint inhibitors in solid tumors settings. Early results from phase I trial showed an excellent safety profile with very promising results $(10,80)$. For instance, in combination with anti-PD-1 (Pembrolizumab), 6 out 23 patients with various types of advanced cancers reported complete or partial responses including a durable complete response in one patient with small cell lung cancer (10).

\section{CD40}

CD40 is a member of TNF receptor family, expressed on APC, macrophages, B lymphocytes and various other types of cells including tumors (81). The main known function of CD40 is that of inducing macrophages activation with consequent increase in cytokines secretion and stimulation of activated $\mathrm{T}$ helper lymphocytes that express the corresponding ligand (CD40L or CD154), a crucial step in the induction of adaptive immune responses (82). Various and heterogeneous functions however may be attributed to CD40, depending on the expressing cells and context (82). Preclinical models supported the antitumor effect of monotherapy with CD40 agonists, in various hematologic 
and solid tumor settings (83). Clinical trials are exploring multiple CD40 agonist antibodies with promising results. Overall, as monotherapy the response rate is around $20 \%$, with some remarkably long-lasting responses $(81,84-86)$. The safety profile appears favorable, even if it was associated with liver toxicity, platelet count decrease and infusionrelated reactions.

It is foreseeable that further explorations of CD 40 agonists will include combinations with other agents, like chemotherapy, radiotherapy or obviously other checkpoint modulators.

\section{CD27-CD70}

$\mathrm{CD} 27$ is a potent co-stimulatory molecule that, following the first activatory signal by TCR, is important for the clonal expansion of naïve $\mathrm{T}$ cells and differentiation into effector cytotoxic lymphocytes. Its ligand is the CD70 molecule, mainly expressed by activated lymphocytes and mediating B cell activation and immunoglobulin production. Following promising preclinical data with stimulatory monoclonal antibodies, clinical explorations are ongoing with agonists of the CD27-CD70 axis. They are either targeting CD70 or CD27. Early results with anti-CD70 Abs reported a promising rate of disease stabilizations in various types of advanced cancers, with fatigue being a common side effect (10). A humanized agonistic anti-CD27 antibody is also under exploration in phase I/II trials against multiple solid tumor malignancies, including CRC, NSCLC, ovarian and head and neck tumors (10). The safety profile appears acceptable also in this case and reports of activity are awaited. As for the previous stimulatory molecules, the targeting of CD27-CD70 is also being explored, with reasonable expectations, in combination with PD-1/PD-L1 or CTLA-4 blockage. A summary of main clinical trials targeting lymphocyte-stimulatory checkpoints is reported in Table 1.

\section{Inhibitory checkpoints}

\section{Lymphocyte activation gene 3 (LAG-3)}

LAG-3 is a membrane receptor expressed by activated T lymphocytes and Tregs (87). It is believed to physiologically contribute to control the "size" of $\mathrm{CD} 8^{+} \mathrm{T}$ cell clonal expansion following their priming and to enhance the suppressor activity of Tregs (88-91). The main ligand is represented by MHC class-II molecules on APCs (88). Along with PD-1, the membrane expression of LAG-3 is associated with an exhaustion profile of tumor infiltrating lymphocytes, correlated with negative clinical features (92-98). Preclinical models confirmed the possibility to restore $\mathrm{T}$ cell antitumor function by LAG-3 blocking, associated with reduction of Tregs activity $(99,100)$. Notably, a soluble form of LAG-3 may be found with ability to stimulate APCs and reinvigorate the immune response (101). Clinically, LAG3 blocking antibodies are under evaluation in early phase clinical trials, either alone or in combination with antiPD-1 antibodies $(9,10)$. Biologically it could be speculated that the generation of new $\mathrm{T}$ cell clones may be favored by anti-LAG-3, helping to react against the clonal evolution of tumor neoantigens. Moreover a soluble LAG-3 isoform antibody is being explored as APC immune-stimulatory agent in advanced cancers (102).

\section{T-cell immunoglobulin- and mucin-domain-containing molecule 3 (TIM-3)}

TIM-3, is a membrane inhibitory receptor expressed by Th1 $\mathrm{CD}^{+}$and $\mathrm{CD} 8^{+} \mathrm{T}$ cells (103). More recently it was also found on Tregs $(104,105)$, Th17 (106) and elements of the innate immune response (107-109). Its main ligand is galactine-9, a widely expressed lectin detectable in multiple organs in physiologic and inflammatory/pathologic conditions (110). TIM-3 engagement determines functional inhibition and apoptosis in T cells (111-113), while enhancing the immune-suppressive activity of Tregs $(114,115)$. Tumor infiltrating lymphocytes co-expressing TIM-3 and PD-1 have been described in several tumor settings, both solid and hematologic, associated with exhausted functions (116-122). This is in line with the experimental observations that a single blocking TIM-3 did not induce relevant antitumor immune responses but much better results may derive from the concomitant association of anti-PD-1 blockers (121-124). Conversely, it is likely that the expression of TIM-3 associates with the development of resistance to $\mathrm{PD}-1 / \mathrm{PD}-\mathrm{L} 1$ blocking, offering possible therapeutic opportunities in this setting $(119,125)$.

Currently early clinical trials are exploring TIM-3 blocking in clinical settings of advanced cancers, mainly exploiting its association with PD-1/PD-L1 inhibitors $(9,10)$.

\section{T cell immunoglobulin and ITIM domain (TIGIT)}

TIGIT is another interesting negative checkpoint expressed 
Table 1 Main clinical trials involving agents targeting lymphocyte-activating immune checkpoints

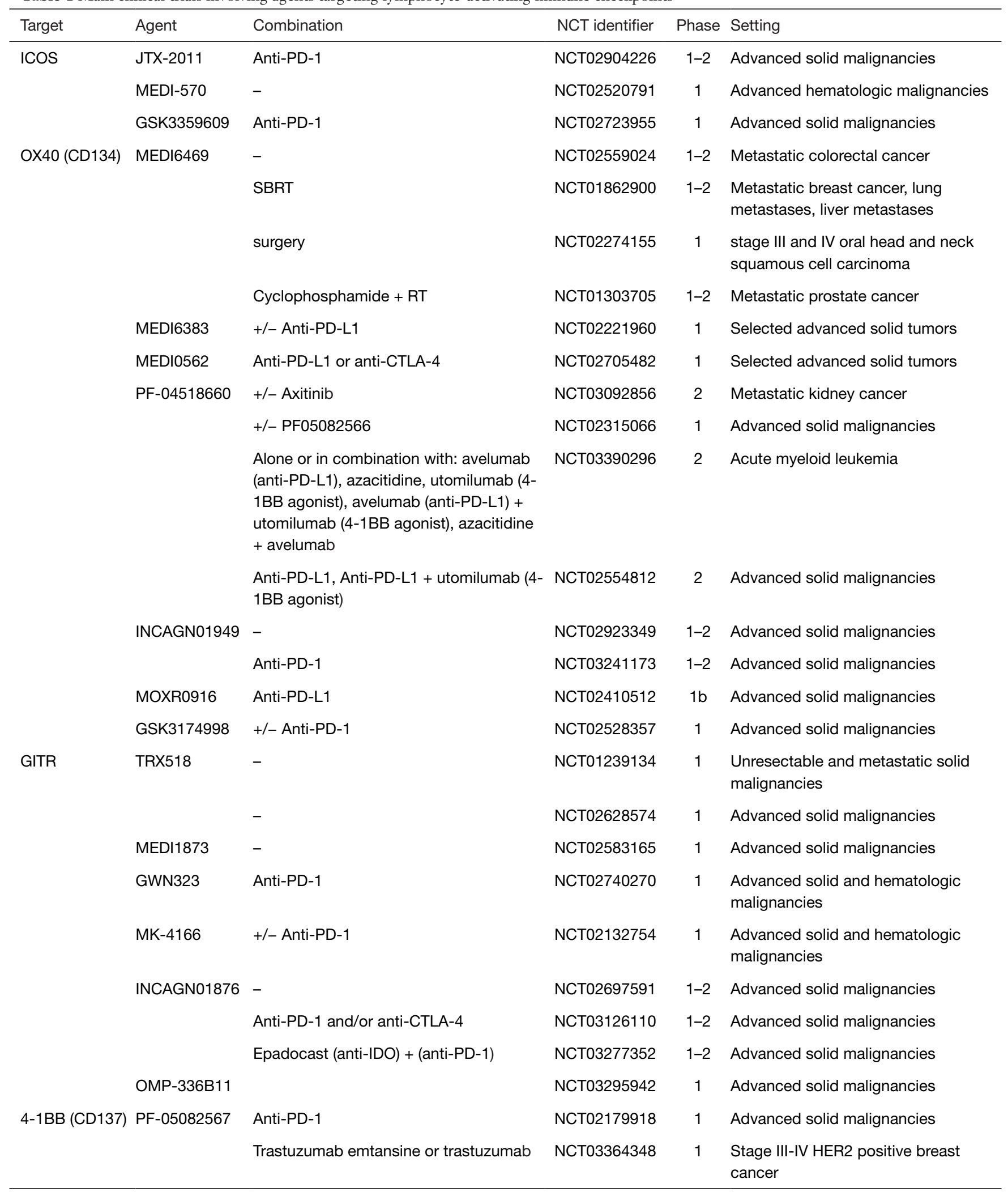

Table 1 (continued) 
Table 1 (continued)

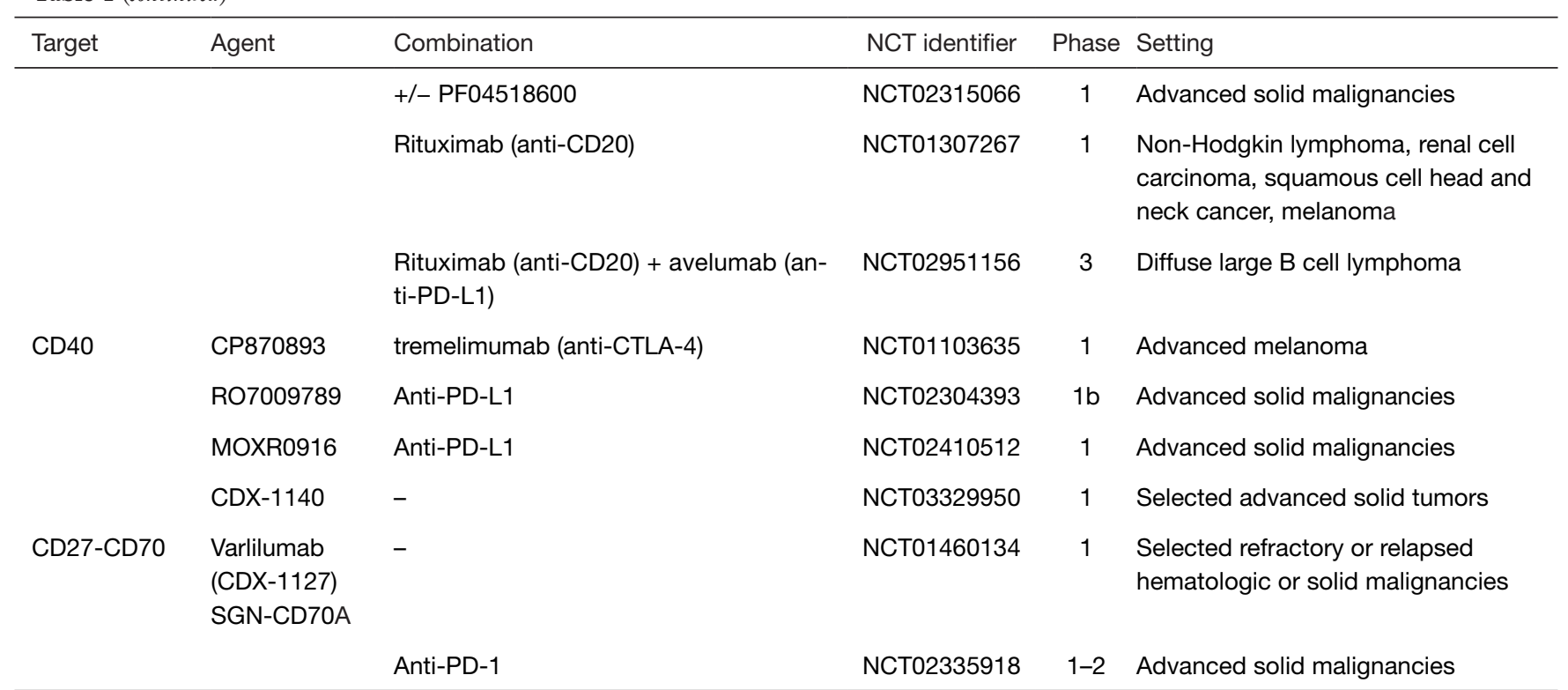

SBRT, stereotactic body radiation therapy.

by $\mathrm{T}$ lymphocytes and NK. Its ligands, mainly present at APC level, are the lectins CD155 and CD112 (126). It is interesting to note that TIGIT is part of a complex regulatory system together with CD96 and CD226 (DNAM-1) receptors (127). They all bind CD155, but while the resulting signal is inhibitory in the cases of TIGIT and CD96, it is activatory for DNAM-1, a situation similar to what is known for the CTLA-4/CD28/B 7 complex. This system contributes to the fine tuning of the immune response, especially regarding NK cells. Similarly to what reported above for TIM-3, TIGIT ${ }^{+}$lymphocytes have been reported to infiltrate several types of tumors in patients, including melanoma, colon, renal and breast cancer $(93,128-131)$. Its expression is often associated with other negative checkpoints like PD-1 and TIM-3 (93). Preclinical models confirmed that TIGIT blockages may induce important antitumor responses, with lymphocyte reactivation $(128,129)$. The clinical development of TIGITblocking antibodies is ongoing, even in this case there are attempts to explore combinations with blockers of PD-1/ PD-L1 axis (9).

\section{V-domain Ig suppressor of T-cell activation (VISTA)}

VISTA is a negative immune-checkpoint structurally analogue to PD-L1, mainly expressed by APC, myeloid cells but also $\mathrm{T}$ lymphocytes and Tregs. VISTA, whereof receptor has still to be clearly identified, is capable of inhibiting $\mathrm{T}$ cell proliferation along with IFN- $\gamma$ and TNF $\alpha$ production. It was also described to enhance the conversion of naïve T lymphocytes into Tregs (132).

In preclinical models it was confirmed that, even if structurally analogue to PD-L1, the role of VISTA is functionally distinct from that the PD-1/PD-L1 axis in controlling T-cell activation (133). Blockage of VISTA resulted in enhanced $\mathrm{T}$ cell infiltration, concomitantly with reduction of myeloid derived suppressor cells (134), with beneficial antitumor responses enhanced by combination with anti-PD-1/PD-L1 $(132,133)$. VISTA ${ }^{+}$lymphocytes have been reported to infiltrate relevant rates of gastric cancers (135). The expression of VISTA may contribute to a compensatory mechanism following treatment with checkpoint inhibitors, suggested by its presence in lymphocytes and M2 macrophages of melanoma or prostate cancer patients that had been previously treated with Ipilimumab (136). Early clinical trials are exploring VISTA blockage in advanced cancers and it is foreseeable its next evaluation in combination with other checkpoint inhibitors $(9,10)$. Of note, an oral small-molecule inhibiting both VISTA and PD-L1 has been developed with promising preclinical data and ongoing clinical testing (10).

A summary of main clinical trials targeting lymphocyteinhibitory checkpoints is reported in Table 2. 
Table 2 Main clinical trials involving agents targeting lymphocyte-inhibiting immune checkpoints

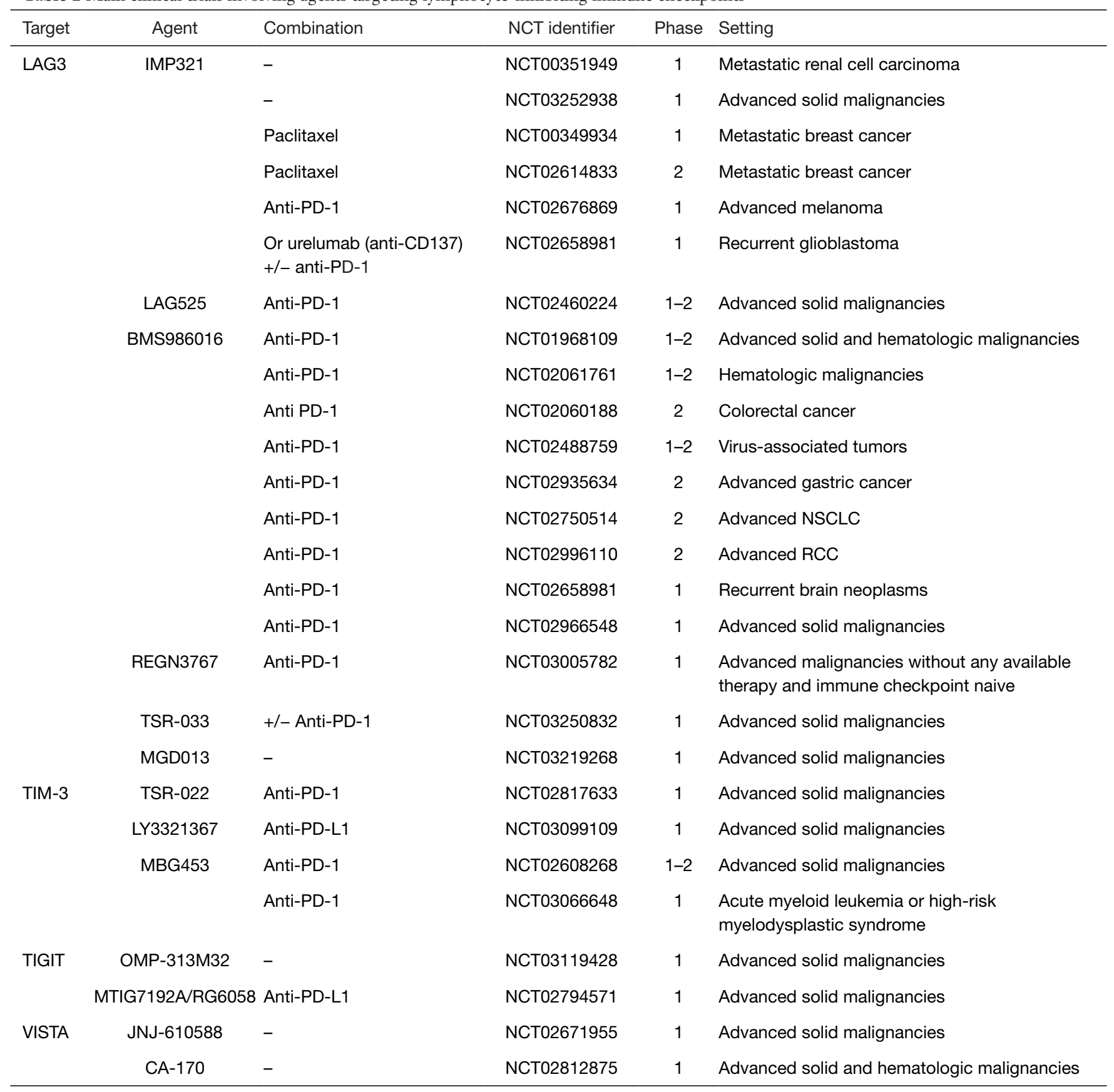

\section{Additional checkpoints of innate immunity CD47/SIRPa}

CD47 is a cell-surface immunoglobulin ubiquitously expressed by normal tissues (137). SIRP $\alpha$ (signal-regulatory protein alpha), its ligand, is a cell-surface immunoglobulin mainly expressed by macrophages and dendritic cells (138). Physiological role of CD47 is to protect viable erythrocytes from phagocytosis (139-144).

CD47/SIRP $\alpha$ is a "don't eat me signal" that inhibits phagocytosis suppressing myosin-II accumulation at phagocytic synapse and respiratory burst $(145,146)$. CD47 
on naïve $T$ cell induces differentiation in regulatory $T$ cells (Tregs) and inhibits development of T helper 1 cells (Th1) $(147,148)$.

Evasion of phagocytosis prevents tumor cell presentation by APCs and indirectly decreases T cell activation (149).

Several cancers express high levels of CD47 and high CD47 mRNA expression correlates with poor clinical prognosis $(9,150-154)$.

CD47/SIRP $\alpha$ axis blockade induces human and mouse macrophages phagocytosis of cancer cells in vitro and shows antitumor activity in xenograft models (152-158).

Early phase clinical trials investigate toxicity and activity of this axis blockade (158).

\section{IDO}

Indoleamine-2,3-dioxygenase (IDO-two isoforms: IDO1, IDO2) is an intracellular enzyme involved in oxidative catabolism of tryptophan, expressed by macrophages and dendritic cells (159-162). It catalyses conversion of L-tryptophan to $\mathrm{N}$-formyl kynurenine by cleavage of the 2,3-double bond (163). Depletion of tryptophan reduces $\mathrm{T}$ cells proliferation while presence of kynurenine induces apoptosis of Th1 and naïve $\mathrm{T}$ cells differentiation in Tregs (164-168).

In this way, IDO activity contributes to create an immune-suppressed environment and to generate tumor tolerance.

Inflammatory cytokines as IFN- $\gamma$, IL- 6 and TNF- $\alpha$ can induce IDO expression (169).

IDO is expressed by most human cancer types and, in clinical studies, its expression levels correlate with lower overall survival (OS), progression-free survival (PFS) and response to chemotherapy, radiotherapy and immunotherapy (159-162,164-173).

Preclinical studies demonstrate that transfecting tumor cell lines with IDO impairs their immune rejection in tumor antigen-immunized mice. On the contrary, IDO inhibitors stimulate $\mathrm{T}$ cell response and inhibit tumor progression in mouse models (173-175).

Actually, clinical trials are investigating several small molecule inhibitors of IDO. Among these, epacadostat has entered phase III clinical development and is undergoing its evaluation in combination with anti-PD-1 (pembrolizumab) for metastatic melanoma $(10,176)$.

A more complete knowledge of the role of IDO isoforms and their affected pathways in mediating tumor immunesuppression is necessary to improve clinical development of
IDO inhibitors (10).

\section{NK cell markers}

\section{CD94/NKG2A}

NK cells have MHC class I-specific inhibitory and activating receptors that control their responsiveness on self-cells and their killing activity against non-self-cells that have lost or downregulated MHC class I.

This process is called "licensing" and is based on shifts of the receptors balance towards NK activation or NK inhibition. The heterodimer formed by CD94, an invariant chain receptor, and $\mathrm{NKG} 2 \mathrm{~A}$, member of $\mathrm{C}$ type lectin like family, is part of these $\mathrm{NK}$ inhibitory receptors while the CD94/NKG2C and CD94/NKG2E are activating heterodimers (177-179).

CD94/NKG2A receptor is also expressed by $\mathrm{T}$ cells. CD94/NKG2A receptor binds to MHC class I HLA-E to carry out its inhibition of $\mathrm{NK}$ cells and T cells activation (180).

Some solid cancers overexpress HLA-E and this overexpression is associated with poor prognosis (181-183).

CD94/NKG2A ${ }^{+}$NK cells with lower cytotoxic potential are found elevated in peripheral blood samples and in intratumoral region of several cancer patients (181-190).

The rationale of $\mathrm{NKG} 2 \mathrm{~A}$ blockade is to improve $\mathrm{NK}$ cell-mediated ADCC and to increase availability of ligands on tumor cells for activating NK receptors with same specificity of CD94/NKG2A receptor (180).

Monalizumab (IPH2201) enhances NK cell response to $\mathrm{HLA}^{+}$tumor cells in preclinical models (191).

Phase I/II trials are assessing activity and safety of NKG2A antibody, some in monotherapy and others in combination with PD-1/PDL-1 axis inhibitors $(9,180)$.

CD94/NKG2A blockade can also be obtained by targeting ERAP-1, that positively modifies ability of specific ligands to engage several classes of NK inhibitory receptors on human tumor cell lines (192).

\section{Killer immunoglobulin-like receptors (KIRs)}

KIR family includes several receptors expressed by NK cells and by some T cells. Some members (KIR2DL1-2-3 and KIR3DL1) of this family are able to impair NK selfrecognition. HLA-A, HLA-B and HLA-C are ligands of these inhibitory KIRs and ligand-receptor interaction turns off NK activation (193-196).

In vitro assays on patient peripheral blood mononuclear 
cells (PBMC) treated with KIR2DL1 inhibitor (IPH2101) show induction of APC Fc $\gamma$ RI-mediated trogocytosis of KIR2DL1 on NK cells with a consequent decrease of NK cell cytotoxic activity. These findings agree with phase I/II clinical trials that failed to increase disease response treating cancer patients with IPH2101 $(197,198)$.

More studies on KIR2DL activating and inhibitory properties are necessary to explain NK anergy mediated by KIR2DL inhibitors. To overcome this anergy KIR blockade can be combined with stimulatory cytokines treatments (IL2, IL-15), anti-TAA antibodies, other checkpoints inhibitors (anti-PD-1/anti-PD-L1, anti-CTLA-4) or stimulators of NK activation (lenalidomide) (199-201).

Actually, lirilumab (inhibitor KIR2DL1-2-3 - IPH2102) is in ongoing phase I/II clinical trials in combination with anti-PD-1 or anti-CTLA-4 in solid and haematological malignancies with preliminary encouraging results (9).

In cancer patients is described an enrichment in PD- $1^{+}$ NK cells, among the subset of CD $56^{\mathrm{dim}} \mathrm{NKG} 2 \mathrm{~A}^{-} \mathrm{KIR}^{+} \mathrm{NK}$ cells associated with poor anti-tumor activity and reduced proliferation (202-204). This could be a rationale for combination treatments with KIRs blockade or stimulation and anti-PD-1/anti-PD-L1, especially in MHC class I deficient malignancy.

\section{CD96}

CD96 (or TACTILE) is a co-inhibitory receptor constitutively expressed by human NK cells.

CD96 binds nectin (or CD112) and nectin-like ligands, which are upregulated on cell membrane of several tumor cell types, and CD155 (or PVR) $(205,206)$. CD96 ligation of CD155 decreases NK production of IFN- $\gamma$, antagonizing DNAM-1 signalling that induces NK cells cytotoxic activity, sharing same ligands of CD96 $(207,208)$.

In preclinical tumor models, CD96 blockade activity depends on NK cells phenotype (209).

A summary of the main clinical trials targeting additional checkpoints of innate immunity and tumor microenvironment is reported in Table 3.

\section{Conclusive remarks}

The discovery and clinical application of monoclonal antibodies that can therapeutically modulate the immune response is profoundly changing both the present and perspective therapeutic scenario in multiple tumor settings. The progressive comprehension of the complex immune regulatory networks that are in place, with stimulatory and inhibitory pathways, is providing continuous rationale and opportunities to refine the existing treatments, designing innovative strategies to overcome resistances, relapses and enhancing the response rates. It is also progressively emerging that multiple additional effectors [e.g., NK, macrophages, APC, myeloid-derived suppressor cells (MDSC)] beyond T lymphocytes directly or indirectly participate to control the onset, intensity and persistence of antitumor immune responses. Such additional effectors are themselves promising immunotherapy targets. Moreover, they often express the same regulatory checkpoints as $\mathrm{T}$ lymphocytes even if sometimes with different functional sense.

Even considering the important promises hold by the new combinatorial approaches, issues about dose, schedule and settings still require to be defined. Results from early clinical trials are awaited, with early data suggesting a favorable safety profile for most of the new checkpoint modulators, along with interesting but also scattered signs of activity. The "conventional" concepts of trial design and endpoints are challenged by the new biologic knowledge and its continuous evolution. It would be desirable that new clinical studies would, whenever possible, be paralleled by translational studies that might provide immunological insights to interpreter both events of responses and resistance, providing reliable basis for subsequent adjustments and study designing. Ideally the future treatment strategies will trend toward personalized approaches accounting for the individual biological complexity and costs considerations. In this perspective the concept of predictive biomarkers will likely evolve in wider concepts of "predictive immunological landscapes" including the multiple cellular, molecular and metabolic variables that might simultaneously impact the antitumor immune responses.

It is necessary to patiently await for the advancements of scientific knowledge and biological rational rather than to attempt random associations of these many new compounds. Important efforts are needed at multiple levels, from the academia to the regulatory agencies. It will be important to define a positive compromise between the comprehensible need for prompt "clinically useful" answers and the necessary time to develop the appropriate parallel biological comprehension. 
Table 3 Main clinical trials involving agents targeting macrophage and NK immune markers

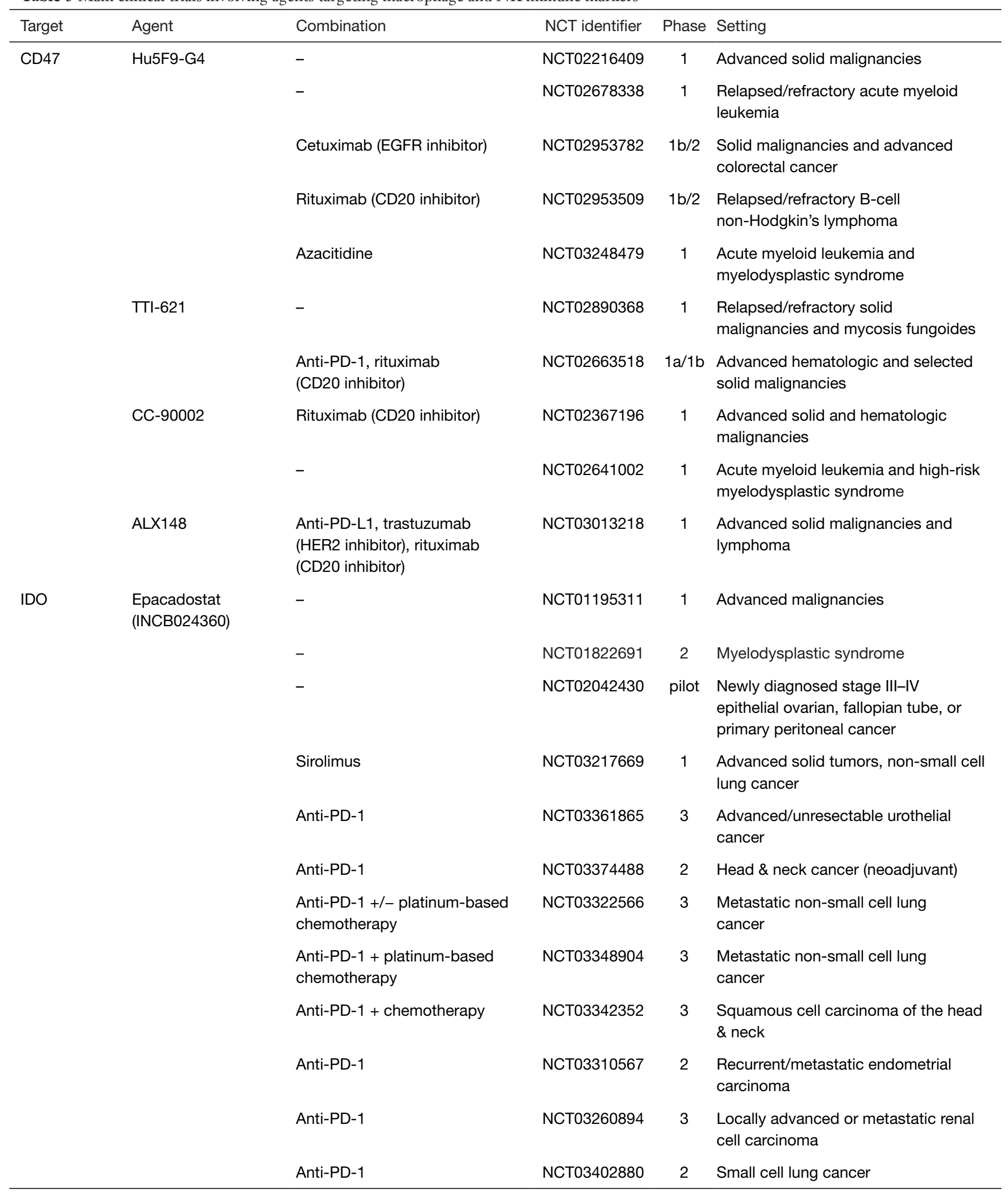

Table 3 (continued) 
Table 3 (continued)

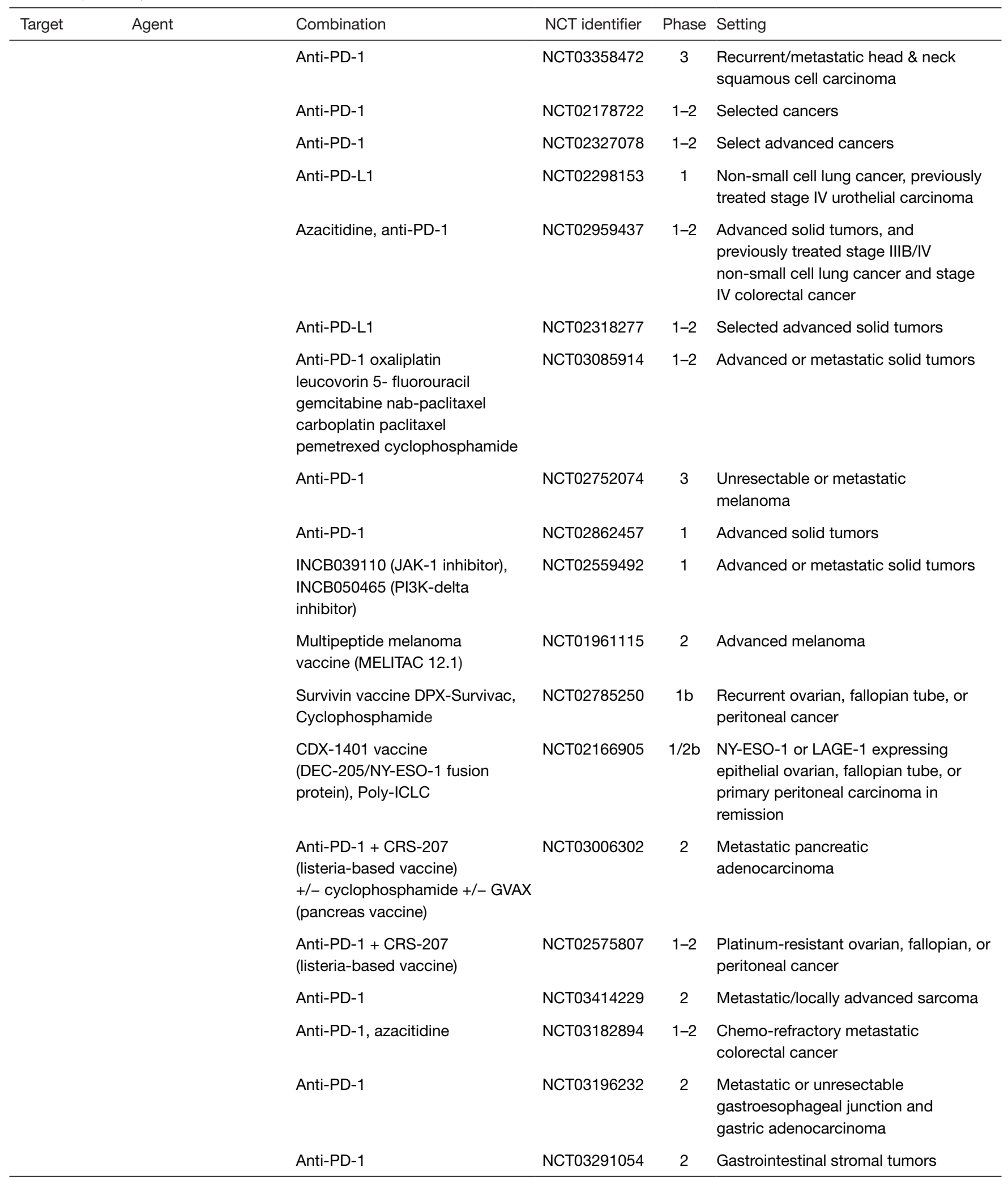

Table 3 (continued) 
Table 3 (continued)

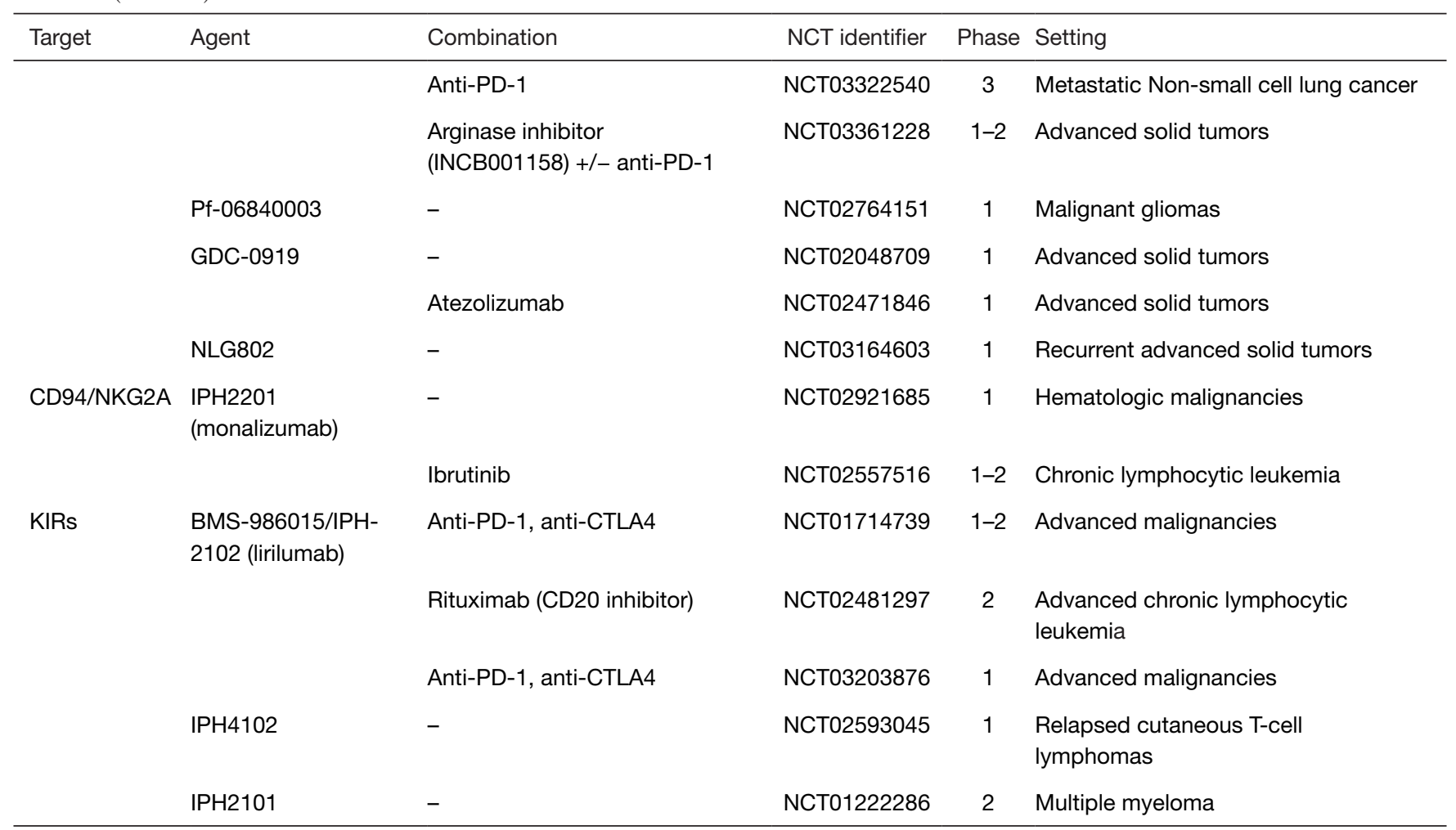

\section{Acknowledgements}

Funding: This work was supported in part by FPRC ONLUS $5 \times 1000$, Ministero della Salute 2012; Ricerca Finalizzata-Giovani Ricercatori Ministero della Salute (GR2011-02349197); AIRC MFAG 2014 N.15731.

\section{Footnote}

Conflicts of Interest: The authors have no conflicts of interest to declare.

\section{References}

1. Zou W, Chen L. Inhibitory B7-family molecules in the tumour microenvironment. Nat Rev Immunol 2008;8:467-77.

2. Wolchok JD, Chiarion-Sileni V, Gonzalez R, et al. Overall survival with combined nivolumab and ipilimumab in advanced melanoma. N Engl J Med 2017;377:1345-56.

3. Robert C, Schachter J, Long GV, et al. Pembrolizumab versus ipilimumab in advanced melanoma. $\mathrm{N}$ Engl $\mathrm{J}$ Med 2015;372:2521-32.
4. Herbst RS, Baas P, Kim DW, et al. Pembrolizumab versus docetaxel for previously treated, PD-L1-positive, advanced non-small-cell lung cancer (KEYNOTE-010): a randomised controlled trial. Lancet 2016;387:1540-50.

5. Reck M, Rodríguez-Abreu D, Robinson AG, et al. Pembrolizumab versus chemotherapy for PD-L1positive non-small-cell lung cancer. N Engl J Med 2016;375:1823-33.

6. Motzer RJ, Escudier B, McDermott DF, et al. Nivolumab versus everolimus in advanced renal-cell carcinoma. $\mathrm{N}$ Engl J Med 2015;373:1803-13.

7. Balar AV, Castellano D, O'Donnell PH, et al. First-line pembrolizumab in cisplatin-ineligible patients with locally advanced and unresectable or metastatic urothelial cancer (KEYNOTE-052): a multicentre, single-arm, phase 2 study. Lancet Oncol 2017;18:1483-92.

8. Ferris RL, Blumenschein G, Fayette J, et al. Nivolumab for recurrent squamous-cell carcinoma of the head and neck. N Engl J Med 2016;375:1856-67.

9. Burugu S, Dancsok AR, Nielsen TO. Emerging targets in cancer immunotherapy. Semin Cancer Biol 2017. [Epub ahead of print]. 
10. Dempke WCM, Fenchel K, Uciechowski P, et al. Second- and third-generation drugs for immunooncology treatment-the more the better? Eur J Cancer 2017;74:55-72.

11. Swallow MM, Wallin JJ, Sha WC. B7h, a novel costimulatory homolog of B7.1 and B7.2, is induced by TNFalpha. Immunity 1999;11:423-32.

12. Ling V, Wu PW, Finnerty HF, et al. Cutting edge: identification of GL50, a novel B7-like protein that functionally binds to ICOS receptor. J Immunol 2000;164:1653-7.

13. Yoshinaga SK, Whoriskey JS, Khare SD, et al. T-cell co-stimulation through B7RP-1 and ICOS. Nature 1999;402:827-32.

14. Brodie D, Collins AV, Iaboni A, et al. LICOS, a primordial costimulatory ligand? Curr Biol 2000;10:333-6.

15. Wang S, Zhu G, Chapoval AI, et al. Costimulation of T cells by B7-H2, a B7-like molecule that binds ICOS. Blood 2000;96:2808-13.

16. Aicher A, Hayden-Ledbetter M, Brady WA, et al. Characterization of human inducible costimulator ligand expression and function. J Immunol 2000;164:4689-96.

17. Yoshinaga SK, Zhang M, Pistillo J, et al. Characterization of a new human B7-related protein: B7RP-1 is the ligand to the co-stimulatory protein ICOS. Int Immunol 2000;12:1439-47.

18. Richter G, Hayden-Ledbetter M, Irgang M, et al. Tumor necrosis factor-alpha regulates the expression of inducible costimulator receptor ligand on CD34(+) progenitor cells during differentiation into antigen presenting cells. J Biol Chem 2001;276:45686-93.

19. Zhang Y, Luo Y, Qin SL, et al. The clinical impact of ICOS signal in colorectal cancer patients.

Oncoimmunology 2016;5:e1141857.

20. Coyle AJ, Lehar S, Lloyd C, et al. The CD28-related molecule ICOS is required for effective $\mathrm{T}$ cell-dependent immune responses. Immunity 2000;13:95-105.

21. Gigoux M, Lovato A, Leconte J, et al. Inducible costimulator facilitates T-dependent B cell activation by augmenting IL-4 translation. Mol Immunol 2014;59:46-54.

22. Lee H, Kim JH, Yang SY, et al. Peripheral blood gene expression of B7 and CD28 family members associated with tumor progression and microscopic lymphovascular invasion in colon cancer patients. J Cancer Res Clin Oncol 2010;136:1445-52.

23. Carthon BC, Wolchok JD, Yuan J, et al. Preoperative CTLA-4 blockade: tolerability and immune monitoring in the setting of a presurgical clinical trial. Clin Cancer Res
2010;16:2861-71.

24. Di Giacomo AM, Calabrò L, Danielli R, et al. Longterm survival and immunological parameters in metastatic melanoma patients who responded to ipilimumab 10 $\mathrm{mg} / \mathrm{kg}$ within an expanded access programme. Cancer Immunol Immunother 2013;62:1021-8.

25. Faget J, Bendriss-Vermare N, Gobert M, et al. ICOSligand expression on plasmacytoid dendritic cells supports breast cancer progression by promoting the accumulation of immunosuppressive CD4+ T cells. Cancer Res 2012;72:6130-41.

26. Faget J, Sisirak V, Blay JY, et al. ICOS is associated with poor prognosis in breast cancer as it promotes the amplification of immunosuppressive CD4+ T cells by plasmacytoid dendritic cells. Oncoimmunology 2013;2:e23185.

27. Fan X, Quezada SA, Sepulveda MA, et al. Engagement of the ICOS pathway markedly enhances efficacy of CTLA-4 blockade in cancer immunotherapy. J Exp Med 2014;211:715-25.

28. Fu T, He Q, Sharma P. The ICOS/ICOSL pathway is required for optimal antitumor responses mediated by anti-CTLA-4 therapy. Cancer Res 2011;71:5445-54.

29. Kamphorst AO, Pillai RN, Yang S, et al. Proliferation of PD-1+ CD8 T cells in peripheral blood after PD-1targeted therapy in lung cancer patients. Proc Natl Acad Sci U S A 2017;114:4993-8.

30. Vonderheide RH, LoRusso PM, Khalil M, et al. Tremelimumab in combination with exemestane in patients with advanced breast cancer and treatmentassociated modulation of inducible costimulator expression on patient T cells. Clin Cancer Res 2010;16:3485-94.

31. Tang C, Welsh JW, de Groot P, et al. Ipilimumab with stereotactic ablative radiation therapy: phase $\mathrm{i}$ results and immunologic correlates from peripheral T Cells. Clin Cancer Res 2017;23:1388-96.

32. Heeren AM, Koster BD, Samuels S, et al. High and interrelated rates of PD-L1+CD14+ antigen-presenting cells and regulatory $T$ cells mark the microenvironment of metastatic lymph nodes from patients with cervical cancer. Cancer Immunol Res 2015;3:48-58.

33. Paterson DJ, Jefferies WA, Green JR, et al. Antigens of activated rat $\mathrm{T}$ lymphocytes including a molecule of $50,000 \mathrm{Mr}$ detected only on CD4 positive T blasts. Mol Immunol 1987;24:1281-90.

34. Mallett S, Fossum S, Barclay AN. Characterization of the MRC OX40 antigen of activated CD4 positive $T$ lymphocytes--a molecule related to nerve growth factor 
receptor. EMBO J 1990;9:1063-8.

35. Croft M. Control of immunity by the TNFRrelated molecule OX40 (CD134). Annu Rev Immunol 2010;28:57-78.

36. Valzasina B, Guiducci C, Dislich H, et al. Triggering of OX40 (CD134) on CD4(+)CD25+ T cells blocks their inhibitory activity: a novel regulatory role for OX40 and its comparison with GITR. Blood 2005;105:2845-51.

37. Baumann R, Yousefi S, Simon D, et al. Functional expression of CD134 by neutrophils. Eur J Immunol 2004;34:2268-75.

38. Baum PR, Gayle RB, Ramsdell F, et al. Molecular characterization of murine and human OX40/OX40 ligand systems: identification of a human OX40 ligand as the HTLV-1-regulated protein gp34. EMBO J 1994;13:39924001.

39. Godfrey WR, Fagnoni FF, Harara MA, et al. Identification of a human OX-40 ligand, a costimulator of CD4+ T cells with homology to tumor necrosis factor. J Exp Med 1994;180:757-62.

40. Rogers PR, Song J, Gramaglia I, et al. OX40 promotes $\mathrm{Bcl}-\mathrm{xL}$ and $\mathrm{Bcl}-2$ expression and is essential for long-term survival of CD4 T cells. Immunity 2001;15:445-55.

41. Song J, So T, Cheng M, et al. Sustained survivin expression from OX40 costimulatory signals drives T cell clonal expansion. Immunity 2005;22:621-31.

42. So T, Song J, Sugie K, et al. Signals from OX40 regulate nuclear factor of activated $\mathrm{T}$ cells $\mathrm{c} 1$ and $\mathrm{T}$ cell helper 2 lineage commitment. Proc Natl Acad Sci U S A 2006;103:3740-5.

43. Linch SN, McNamara MJ, Redmond WL. OX40 Agonists and Combination Immunotherapy: putting the pedal to the metal. Front Oncol 2015;5:34.

44. Ruby CE, Yates MA, Hirschhorn-Cymerman D, et al. Cutting Edge: OX40 agonists can drive regulatory $\mathrm{T}$ cell expansion if the cytokine milieu is right. J Immunol 2009; 183:4853-7.

45. Weinberg AD, Rivera MM, Prell R, et al. Engagement of the $\mathrm{OX}-40$ receptor in vivo enhances antitumor immunity. J Immunol 2000;164:2160-9.

46. Kjaergaard J, Tanaka J, Kim JA, et al. Therapeutic efficacy of OX-40 receptor antibody depends on tumor immunogenicity and anatomic site of tumor growth. Cancer Res 2000;60:5514-21.

47. Redmond WL, Gough MJ, Weinberg AD. Ligation of the OX40 co-stimulatory receptor reverses self-Ag and tumor-induced CD8 T-cell anergy in vivo. Eur J Immunol 2009;39:2184-94.
48. Weinberg AD, Morris NP, Kovacsovics-Bankowski M, et al. Science gone translational: the OX40 agonist story. Immunol Rev 2011;244:218-31.

49. Hirschhorn-Cymerman D, Rizzuto GA, Merghoub T, et al. OX40 engagement and chemotherapy combination provides potent antitumor immunity with concomitant regulatory T cell apoptosis. J Exp Med 2009;206:1103-16.

50. Gough MJ, Crittenden MR, Sarff M, et al. Adjuvant therapy with agonistic antibodies to CD134 (OX40) increases local control after surgical or radiation therapy of cancer in mice. J Immunother 2010;33:798-809.

51. Curti BD, Kovacsovics-Bankowski M, Morris N, et al. OX40 is a potent immune-stimulating target in late-stage cancer patients. Cancer Res 2013;73:7189-98.

52. Aspeslagh S, Postel-Vinay S, Rusakiewicz S, et al. Rationale for anti-OX40 cancer immunotherapy. Eur J Cancer 2016;52:50-66.

53. Shimizu J, Yamazaki S, Takahashi T, et al. Stimulation of CD25(+)CD4(+) regulatory T cells through GITR breaks immunological self-tolerance. Nat Immunol 2002;3:135-42.

54. McHugh RS, Whitters MJ, Piccirillo CA, et al. CD4(+) CD25(+) immunoregulatory $T$ cells: gene expression analysis reveals a functional role for the glucocorticoidinduced TNF receptor. Immunity 2002;16:311-23.

55. Gurney AL, Marsters SA, Huang RM, et al. Identification of a new member of the tumor necrosis factor family and its receptor, a human ortholog of mouse GITR. Curr Biol 1999;9:215-8.

56. Ronchetti S, Zollo O, Bruscoli S, et al. GITR, a member of the TNF receptor superfamily, is costimulatory to mouse T lymphocyte subpopulations. Eur J Immunol 2004;34:613-22.

57. Schaer DA, Murphy JT, Wolchok JD. Modulation of GITR for cancer immunotherapy. Curr Opin Immunol 2012;24:217-24.

58. Snell LM, McPherson AJ, Lin GH, et al. CD8 T cellintrinsic GITR is required for T cell clonal expansion and mouse survival following severe influenza infection. J Immunol 2010;185:7223-34.

59. Knee DA, Hewes B, Brogdon JL. Rationale for anti-GITR cancer immunotherapy. Eur J Cancer 2016;67:1-10.

60. Snell LM, Lin GH, McPherson AJ, et al. T-cell intrinsic effects of GITR and 4-1BB during viral infection and cancer immunotherapy. Immunol Rev 2011;244:197-217.

61. Coe D, Begom S, Addey C, et al. Depletion of regulatory T cells by anti-GITR mAb as a novel mechanism for cancer immunotherapy. Cancer Immunol Immunother 
2010;59:1367-77.

62. Aida K, Miyakawa R, Suzuki K, et al. Suppression of Tregs by anti-glucocorticoid induced TNF receptor antibody enhances the antitumor immunity of interferon- $\alpha$ gene therapy for pancreatic cancer. Cancer Sci 2014;105:159-67.

63. Cohen AD, Schaer DA, Liu C, et al. Agonist anti-GITR monoclonal antibody induces melanoma tumor immunity in mice by altering regulatory $\mathrm{T}$ cell stability and intratumor accumulation. PLoS One 2010;5:e10436.

64. Duan F, Lin Y, Liu C, et al. Immune rejection of mouse tumors expressing mutated self. Cancer Res 2009;69:3545-53

65. Zhou P, Qiu J, L'Italien L, et al. Mature B cells are critical to T-cell-mediated tumor immunity induced by an agonist anti-GITR monoclonal antibody. J Immunother 2010;33:789-97.

66. Lu L, Xu X, Zhang B, et al. Combined PD-1 blockade and GITR triggering induce a potent antitumor immunity in murine cancer models and synergizes with chemotherapeutic drugs. J Transl Med 2014;12:36.

67. Yu N, Fu S, Xu Z, et al. Synergistic antitumor responses by combined GITR activation and sunitinib in metastatic renal cell carcinoma. Int J Cancer 2016;138:451-62.

68. Kim IK, Kim BS, Koh CH, et al. Glucocorticoid-induced tumor necrosis factor receptor-related protein costimulation facilitates tumor regression by inducing IL-9producing helper T cells. Nat Med 2015;21:1010-7.

69. Zhu LX, Davoodi M, Srivastava MK, et al. GITR agonist enhances vaccination responses in lung cancer. Oncoimmunology 2015;4:e992237.

70. Brunn ND, Mauze S, Gu D, et al. The role of anti-drug antibodies in the pharmacokinetics, disposition, target engagement, and efficacy of a GITR agonist monoclonal antibody in mice. J Pharmacol Exp Ther 2016;356:574-86.

71. Leyland R, Watkins A, Mulgrew KA, et al. A novel murine GITR ligand fusion protein induces antitumor activity as a monotherapy that is further enhanced in combination with an OX40 Agonist. Clin Cancer Res 2017;23:3416-27.

72. Berman D, Korman A, Peck R, et al. The development of immunomodulatory monoclonal antibodies as a new therapeutic modality for cancer: the Bristol-Myers Squibb experience. Pharmacol Ther 2015;148:132-53.

73. Melero I, Murillo O, Dubrot J, et al. Multi-layered action mechanisms of CD137 (4-1BB)-targeted immunotherapies. Trends Pharmacol Sci 2008;29:383-90.

74. Vinay DS, Kwon BS. 4-1BB signaling beyond T cells. Cell Mol Immunol 2011;8:281-4.
75. Melero I, Hervas-Stubbs S, Glennie M, et al. Immunostimulatory monoclonal antibodies for cancer therapy. Nat Rev Cancer 2007;7:95-106.

76. Alderson MR, Smith CA, Tough TW, et al. Molecular and biological characterization of human 4-1BB and its ligand. Eur J Immunol 1994;24:2219-27.

77. Lin W, Voskens CJ, Zhang X, et al. Fc-dependent expression of CD137 on human NK cells: insights into "agonistic" effects of anti-CD137 monoclonal antibodies. Blood 2008;112:699-707.

78. Takeda K, Kojima Y, Uno T, et al. Combination therapy of established tumors by antibodies targeting immune activating and suppressing molecules. J Immunol 2010;184:5493-501.

79. Wilcox RA, Tamada K, Strome SE, et al. Signaling through NK cell-associated CD137 promotes both helper function for CD8+ cytolytic T cells and responsiveness to IL-2 but not cytolytic activity. J Immunol 2002;169:42306.

80. Curran MA, Kim M, Montalvo W, et al. Combination CTLA-4 blockade and 4-1BB activation enhances tumor rejection by increasing T-cell infiltration, proliferation, and cytokine production. PLoS One 2011;6:e19499.

81. Vonderheide RH. Prospect of targeting the CD40 pathway for cancer therapy. Clin Cancer Res 2007;13:1083-8.

82. van Kooten C, Banchereau J. CD40-CD40 ligand. J Leukoc Biol 2000;67:2-17.

83. Tutt AL, O'Brien L, Hussain A, et al. T cell immunity to lymphoma following treatment with anti-CD40 monoclonal antibody. J Immunol 2002;168:2720-8.

84. Vonderheide RH, Dutcher JP, Anderson JE, et al. Phase I study of recombinant human CD40 ligand in cancer patients. J Clin Oncol 2001;19:3280-7.

85. Vonderheide RH, Glennie MJ. Agonistic CD40 antibodies and cancer therapy. Clin Cancer Res 2013;19:1035-43.

86. Moran AE, Kovacsovics-Bankowski M, Weinberg AD. The TNFRs OX40, 4-1BB, and CD40 as targets for cancer immunotherapy. Curr Opin Immunol 2013;25:230-7.

87. Wherry EJ. T cell exhaustion. Nat Immunol 2011;12:492-9.

88. Anderson AC, Joller N, Kuchroo VK. Lag-3, Tim-3, and TIGIT: co-inhibitory receptors with specialized functions in immune regulation. Immunity 2016;44:989-1004.

89. Scurr M, Ladell K, Besneux M, et al. Highly prevalent colorectal cancer-infiltrating LAP $\square$ Foxp3 $\square$ T cells exhibit more potent immunosuppressive activity than Foxp3 $\square$ regulatory T cells. Mucosal Immunol 2014;7:428-39. 
90. Bettini M, Szymczak-Workman AL, Forbes K, et al. Cutting edge: accelerated autoimmune diabetes in the absence of LAG-3. J Immunol 2011;187:3493-8.

91. Williams JB, Horton BL, Zheng Y, et al. The EGR2 targets LAG-3 and 4-1BB describe and regulate dysfunctional antigen-specific CD8+ T cells in the tumor microenvironment. J Exp Med 2017;214:381-400.

92. Shapiro M, Herishanu Y, Katz BZ, et al. Lymphocyte activation gene 3: a novel therapeutic target in chronic lymphocytic leukemia. Haematologica 2017;102:874-82.

93. Tassi E, Grazia G, Vegetti C, et al. Early effector T lymphocytes coexpress multiple inhibitory receptors in primary non-small cell lung cancer. Cancer Res 2017;77:851-61.

94. Bottai G, Raschioni C, Losurdo A, et al. An immune stratification reveals a subset of PD-1/LAG-3 doublepositive triple-negative breast cancers. Breast Cancer Res 2016;18:121.

95. Deng WW, Mao L, Yu GT, et al. LAG-3 confers poor prognosis and its blockade reshapes antitumor response in head and neck squamous cell carcinoma. Oncoimmunology 2016;5:e1239005.

96. Llosa NJ, Cruise M, Tam A, et al. The vigorous immune microenvironment of microsatellite instable colon cancer is balanced by multiple counter-inhibitory checkpoints. Cancer Discov 2015;5:43-51.

97. Meng Q, Liu Z, Rangelova E, et al. Expansion of tumorreactive T Cells From Patients With Pancreatic Cancer. J Immunother 2016;39:81-9.

98. Demeure CE, Wolfers J, Martin-Garcia N, et al. T Lymphocytes infiltrating various tumour types express the MHC class II ligand lymphocyte activation gene-3 (LAG3): role of LAG-3/MHC class II interactions in cell-cell contacts. Eur J Cancer 2001;37:1709-18.

99. Woo SR, Turnis ME, Goldberg MV, et al. Immune inhibitory molecules LAG-3 and PD-1 synergistically regulate T-cell function to promote tumoral immune escape. Cancer Res 2012;72:917-27.

100.Huang RY, Eppolito C, Lele S, et al. LAG3 and PD-1 co-inhibitory molecules collaborate to limit CD8+ T cell signaling and dampen antitumor immunity in a murine ovarian cancer model. Oncotarget 2015;6:27359-77.

101. Casati C, Camisaschi C, Rini F, et al. Soluble human LAG-3 molecule amplifies the in vitro generation of type 1 tumor-specific immunity. Cancer Res 2006;66:4450-60.

102. Romano E, Michielin O, Voelter V, et al. MART1 peptide vaccination plus IMP321 (LAG-3Ig fusion protein) in patients receiving autologous PBMCs after lymphodepletion: results of a Phase I trial. J Transl Med 2014;12:97.

103. Monney L, Sabatos CA, Gaglia JL, et al. Th1-specific cell surface protein Tim-3 regulates macrophage activation and severity of an autoimmune disease. Nature 2002;415:536-41.

104. Gao X, Zhu Y, Li G, et al. TIM-3 expression characterizes regulatory $\mathrm{T}$ cells in tumor tissues and is associated with lung cancer progression. PLoS One 2012;7:e30676.

105. Yan J, Zhang Y, Zhang JP, et al. Tim-3 expression defines regulatory $\mathrm{T}$ cells in human tumors. PLoS One 2013;8:e58006.

106.Hastings WD, Anderson DE, Kassam N, et al. TIM3 is expressed on activated human CD4+ T cells and regulates Th1 and Th17 cytokines. Eur J Immunol 2009;39:2492-501.

107. Gleason MK, Lenvik TR, McCullar V, et al. Tim-3 is an inducible human natural killer cell receptor that enhances interferon gamma production in response to galectin-9. Blood 2012;119:3064-72.

108. Ndhlovu LC, Lopez-Vergès S, Barbour JD, et al. Tim-3 marks human natural killer cell maturation and suppresses cell-mediated cytotoxicity. Blood 2012;119:3734-43.

109. Anderson AC, Anderson DE, Bregoli L, et al. Promotion of tissue inflammation by the immune receptor Tim-3 expressed on innate immune cells. Science 2007;318:1141-3.

110. Wada J, Kanwar YS. Identification and characterization of galectin-9, a novel beta-galactoside-binding mammalian lectin. J Biol Chem 1997;272:6078-86.

111.Zhu C, Anderson AC, Schubart A, et al. The Tim-3 ligand galectin-9 negatively regulates $\mathrm{T}$ helper type 1 immunity. Nat Immunol 2005;6:1245-52.

112. Sabatos CA, Chakravarti S, Cha E, et al. Interaction of Tim-3 and Tim-3 ligand regulates T helper type 1 responses and induction of peripheral tolerance. Nat Immunol 2003;4:1102-10.

113. Sánchez-Fueyo A, Tian J, Picarella D, et al. Tim-3 inhibits $T$ helper type 1-mediated auto- and alloimmune responses and promotes immunological tolerance. Nat Immunol 2003;4:1093-101.

114. Gautron AS, Dominguez-Villar M, de Marcken M, et al. Enhanced suppressor function of TIM-3+ FoxP3+ regulatory T cells. Eur J Immunol 2014;44:2703-11.

115. Gupta S, Thornley TB, Gao W, et al. Allograft rejection is restrained by short-lived TIM-3+PD-1+Foxp3+ Tregs. J Clin Invest 2012;122:2395-404.

116.Lu X, Yang L, Yao D, et al. Tumor antigen-specific CD8+ 
T cells are negatively regulated by PD-1 and Tim-3 in human gastric cancer. Cell Immunol 2017;313:43-51.

117.Linedale R, Schmidt C, King BT, et al. Elevated frequencies of CD8 T cells expressing PD-1, CTLA-4 and Tim-3 within tumour from perineural squamous cell carcinoma patients. PLoS One 2017;12:e0175755.

118.Li Z, Liu X, Guo R, et al. TIM-3 plays a more important role than PD-1 in the functional impairments of cytotoxic T cells of malignant Schwannomas. Tumour Biol 2017;39:1010428317698352.

119. Shayan G, Srivastava R, Li J, et al. Adaptive resistance to anti-PD-1 therapy by Tim-3 upregulation is mediated by the PI3K-Akt pathway in head and neck cancer. Oncoimmunology 2016;6:e1261779.

120. Ceresoli GL, Mantovani A. Immune checkpoint inhibitors in malignant pleural mesothelioma. Lancet Oncol 2017;18:559-61.

121.Sakuishi K, Apetoh L, Sullivan JM, et al. Targeting Tim-3 and PD-1 pathways to reverse T cell exhaustion and restore anti-tumor immunity. J Exp Med 2010;207:2187-94.

122.Zhou Q, Munger ME, Veenstra RG, et al. Coexpression of Tim-3 and PD-1 identifies a CD8+ T-cell exhaustion phenotype in mice with disseminated acute myelogenous leukemia. Blood 2011;117:4501-10.

123. Fourcade J, Sun Z, Benallaoua M, et al. Upregulation of Tim-3 and PD-1 expression is associated with tumor antigen-specific CD8+ $\mathrm{T}$ cell dysfunction in melanoma patients. J Exp Med 2010;207:2175-86.

124. Ngiow SF, von Scheidt B, Akiba H, et al. Anti-TIM3 antibody promotes $\mathrm{T}$ cell IFN- $\gamma$-mediated antitumor immunity and suppresses established tumors. Cancer Res 2011;71:3540-51.

125. Koyama S, Akbay EA, Li YY, et al. Adaptive resistance to therapeutic PD-1 blockade is associated with upregulation of alternative immune checkpoints. Nat Commun 2016;7:10501.

126. Deuss FA, Gully BS, Rossjohn J, et al. Recognition of nectin-2 by the natural killer cell receptor $\mathrm{T}$ cell immunoglobulin and ITIM domain (TIGIT). J Biol Chem 2017;292:11413-22.

127. Dougall WC, Kurtulus S, Smyth MJ, et al. TIGIT and CD96: new checkpoint receptor targets for cancer immunotherapy. Immunol Rev 2017;276:112-20.

128.Johnston RJ, Comps-Agrar L, Hackney J, et al. The immunoreceptor TIGIT regulates antitumor and antiviral CD8(+) T cell effector function. Cancer Cell 2014;26:923-37.
129. Kurtulus S, Sakuishi K, Ngiow SF, et al. TIGIT predominantly regulates the immune response via regulatory T cells. J Clin Invest 2015;125:4053-62.

130.Wang F, Hou H, Wu S, et al. TIGIT expression levels on human NK cells correlate with functional heterogeneity among healthy individuals. Eur J Immunol 2015;45:2886-97.

131. Martínez-Canales S, Cifuentes F, López De Rodas Gregorio M, et al. Transcriptomic immunologic signature associated with favorable clinical outcome in basal-like breast tumors. PLoS One 2017;12:e0175128.

132.Lines JL, Sempere LF, Broughton T, et al. VISTA is a novel broad-spectrum negative checkpoint regulator for cancer immunotherapy. Cancer Immunol Res 2014;2:510-7.

133.Liu J, Yuan Y, Chen W, et al. Immune-checkpoint proteins VISTA and PD-1 nonredundantly regulate murine T-cell responses. Proc Natl Acad Sci U S A 2015;112:6682-7.

134.Le Mercier I, Chen W, Lines JL, et al. VISTA regulates the development of protective antitumor immunity. Cancer Res 2014;74:1933-44.

135.Böger C, Behrens HM, Krüger S, et al. The novel negative checkpoint regulator VISTA is expressed in gastric carcinoma and associated with PD-L1/PD-1: A future perspective for a combined gastric cancer therapy? Oncoimmunology 2017;6:e1293215.

136. Gao J, Ward JF, Pettaway CA, et al. VISTA is an inhibitory immune checkpoint that is increased after ipilimumab therapy in patients with prostate cancer. Nat Med 2017;23:551-5.

137. Reinhold MI, Lindberg FP, Plas D, et al. In vivo expression of alternatively spliced forms of integrin-associated protein (CD47). J Cell Sci 1995;108:3419-25.

138. Fujioka Y, Matozaki T, Noguchi T, et al. A novel membrane glycoprotein, SHPS-1, that binds the SH2domain-containing protein tyrosine phosphatase SHP-2 in response to mitogens and cell adhesion. Mol Cell Biol 1996;16:6887-99.

139. Oldenborg PA, Zheleznyak A, Fang YF, et al. Role of CD47 as a marker of self on red blood cells. Science 2000;288:2051-4.

140. Fossati-Jimack L, Azeredo da Silveira S, Moll T, et al. Selective increase of autoimmune epitope expression on aged erythrocytes in mice: implications in anti-erythrocyte autoimmune responses. J Autoimmun 2002;18:17-25.

141. Khandelwal S, van Rooijen N, Saxena RK. Reduced expression of CD47 during murine red blood cell (RBC) senescence and its role in RBC clearance from the 
circulation. Transfusion 2007;47:1725-32.

142. Olsson M, Nilsson A, Oldenborg PA. Dose-dependent inhibitory effect of CD47 in macrophage uptake of IgGopsonized murine erythrocytes. Biochem Biophys Res Commun 2007;352:193-7.

143. Ishikawa-Sekigami T, Kaneko Y, Okazawa H, et al. SHPS1 promotes the survival of circulating erythrocytes through inhibition of phagocytosis by splenic macrophages. Blood 2006;107:341-8.

144. Yamao T, Noguchi T, Takeuchi O, et al. Negative regulation of platelet clearance and of the macrophage phagocytic response by the transmembrane glycoprotein SHPS-1. J Biol Chem 2002;277:39833-9.

145. Tsai RK, Discher DE. Inhibition of "self" engulfment through deactivation of myosin-II at the phagocytic synapse between human cells. J Cell Biol 2008;180:9891003.

146.van Beek EM, Zarate JA, van Bruggen R, et al. SIRP $\alpha$ controls the activity of the phagocyte NADPH oxidase by restricting the expression of gp91(phox). Cell Rep 2012;2:748-55.

147. Avice MN, Rubio M, Sergerie M, et al. CD47 ligation selectively inhibits the development of human naive $\mathrm{T}$ cells into Th1 effectors. J Immunol 2000;165:4624-31.

148. Grimbert P, Bouguermouh S, Baba N, et al. Thrombospondin/CD47 interaction: a pathway to generate regulatory $\mathrm{T}$ cells from human $\mathrm{CD} 4+\mathrm{CD} 25-\mathrm{T}$ cells in response to inflammation. J Immunol 2006;177:3534-41.

149. Van VQ, Lesage S, Bouguermouh S, et al. Expression of the self-marker $\mathrm{CD} 47$ on dendritic cells governs their trafficking to secondary lymphoid organs. EMBO J 2006;25:5560-8.

150. Manna PP, Frazier WA. CD47 mediates killing of breast tumor cells via Gi-dependent inhibition of protein kinase A. Cancer Res 2004;64:1026-36.

151.Kim MJ, Lee JC, Lee JJ, et al. Association of CD47 with natural killer cell-mediated cytotoxicity of headand-neck squamous cell carcinoma lines. Tumour Biol 2008;29:28-34.

152. Chan KS, Espinosa I, Chao M, et al. Identification, molecular characterization, clinical prognosis, and therapeutic targeting of human bladder tumor-initiating cells. Proc Natl Acad Sci U S A 2009;106:14016-21.

153.Edris B, Weiskopf K, Volkmer AK, et al. Antibody therapy targeting the CD47 protein is effective in a model of aggressive metastatic leiomyosarcoma. Proc Natl Acad Sci U S A 2012;109:6656-61.

154. Willingham SB, Volkmer JP, Gentles AJ, et al. The CD47- signal regulatory protein alpha (SIRPa) interaction is a therapeutic target for human solid tumors. Proc Natl Acad Sci U S A 2012;109:6662-7.

155. Jaiswal S, Jamieson CH, Pang WW, et al. CD47 is upregulated on circulating hematopoietic stem cells and leukemia cells to avoid phagocytosis. Cell 2009;138:271-85.

156. Majeti R, Chao MP, Alizadeh AA, et al. CD47 is an adverse prognostic factor and therapeutic antibody target on human acute myeloid leukemia stem cells. Cell 2009;138:286-99.

157.Xiao Z, Chung H, Banan B, et al. Antibody mediated therapy targeting CD47 inhibits tumor progression of hepatocellular carcinoma. Cancer Lett 2015;360:302-9.

158. Liu J, Wang L, Zhao F, et al. Pre-clinical development of a humanized Anti-CD47 antibody with anti-cancer therapeutic potential. PLoS One 2015;10:e137345.

159. Théate I, van Baren N, Pilotte L, et al. Extensive profiling of the expression of the indoleamine 2,3-dioxygenase 1 protein in normal and tumoral human tissues. Cancer Immunol Res 2015;3:161-72.

160. Kudo Y, Boyd CA, Spyropoulou I, et al. Indoleamine 2,3-dioxygenase: distribution and function in the developing human placenta. J Reprod Immunol 2004;61:87-98.

161.Ligam P, Manuelpillai U, Wallace EM, et al. Localisation of indoleamine 2,3-dioxygenase and kynurenine hydroxylase in the human placenta and decidua: implications for role of the kynurenine pathway in pregnancy. Placenta 2005;26:498-504.

162. Munn DH, Sharma MD, Hou D, et al. Expression of indoleamine 2,3-dioxygenase by plasmacytoid dendritic cells in tumor-draining lymph nodes. J Clin Invest 2004;114:280-90.

163.Maleki Vareki S, Chen D, Di Cresce C, et al. IDO downregulation induces sensitivity to pemetrexed, gemcitabine, FK866, and methoxyamine in human cancer cells. PLoS One 2015;10:e0143435.

164.Munn DH, Zhou M, Attwood JT, et al. Prevention of allogeneic fetal rejection by tryptophan catabolism. Science 1998;281:1191-3.

165.Munn DH, Shafizadeh E, Attwood JT, et al. Inhibition of T cell proliferation by macrophage tryptophan catabolism. J Exp Med 1999;189:1363-72.

166. Mellor AL, Keskin DB, Johnson T, et al. Cells expressing indoleamine 2,3-dioxygenase inhibit $\mathrm{T}$ cell responses. J Immunol 2002;168:3771-6.

167. Fallarino F, Grohmann U, Vacca C, et al. T cell apoptosis by kynurenines. Adv Exp Med Biol 2003;527:183-90. 
168. Yan Y, Zhang GX, Gran B, et al. IDO upregulates regulatory $\mathrm{T}$ cells via tryptophan catabolite and suppresses encephalitogenic $\mathrm{T}$ cell responses in experimental autoimmune encephalomyelitis. J Immunol 2010;185:5953-61.

169. Munn DH, Mellor AL. Indoleamine 2,3-dioxygenase and tumor-induced tolerance. J Clin Invest 2007;117:1147-54.

170. Yamamoto S, Hayaishi O. Tryptophan pyrrolase of rabbit intestine. D- and L-tryptophan-cleaving enzyme or enzymes. J Biol Chem 1967;242:5260-6.

171. Takikawa O, Yoshida R, Kido R, et al. Tryptophan degradation in mice initiated by indoleamine 2,3-dioxygenase. J Biol Chem 1986;261:3648-53.

172. Yamazaki F, Kuroiwa T, Takikawa O, et al. Human indolylamine 2,3-dioxygenase. Its tissue distribution, and characterization of the placental enzyme. Biochem J 1985;230:635-8.

173. Uyttenhove C, Pilotte L, Théate I, et al. Evidence for a tumoral immune resistance mechanism based on tryptophan degradation by indoleamine 2,3-dioxygenase. Nat Med 2003;9:1269-74.

174. Friberg M, Jennings R, Alsarraj M, et al. Indoleamine 2,3-dioxygenase contributes to tumor cell evasion of $\mathrm{T}$ cell-mediated rejection. Int J Cancer 2002;101:151-5.

175. Wainwright DA, Chang AL, Dey M, et al. Durable therapeutic efficacy utilizing combinatorial blockade against IDO, CTLA-4, and PD-L1 in mice with brain tumors. Clin Cancer Res 2014;20:5290-301.

176. Beatty GL, O'Dwyer PJ, Clark J, et al. First-in-Human Phase I study of the oral inhibitor of indoleamine 2,3-Dioxygenase-1 Epacadostat (INCB024360) in patients with advanced solid malignancies. Clin Cancer Res 2017;23:3269-76.

177.Pittari G, Filippini P, Gentilcore G, et al. Revving up natural killer cells and cytokine-induced killer cells against hematological malignancies. Front Immunol 2015;6:230.

178. Kim S, Poursine-Laurent J, Truscott SM, et al. Licensing of natural killer cells by host major histocompatibility complex class I molecules. Nature 2005;436:709-13.

179. Long EO, Kim HS, Liu D, et al. Controlling natural killer cell responses: integration of signals for activation and inhibition. Annu Rev Immunol 2013;31:227-58.

180. Muntasell A, Ochoa MC, Cordeiro L, et al. Targeting NK-cell checkpoints for cancer immunotherapy. Curr Opin Immunol 2017;45:73-81.

181. Gooden M, Lampen M, Jordanova ES, et al. HLA-E expression by gynecological cancers restrains tumorinfiltrating CD8 ${ }^{+} \mathrm{T}$ lymphocytes. Proc Natl Acad Sci U S
A 2011;108:10656-61.

182. Bossard C, Bézieau S, Matysiak-Budnik T, et al. HLA-E/ $\beta 2$ microglobulin overexpression in colorectal cancer is associated with recruitment of inhibitory immune cells and tumor progression. Int J Cancer 2012;131:855-63.

183. Sun C, Xu J, Huang Q, et al. High NKG2A expression contributes to $\mathrm{NK}$ cell exhaustion and predicts a poor prognosis of patients with liver cancer. Oncoimmunology 2016;6:e1264562.

184. Katou F, Ohtani H, Watanabe Y, et al. Differing phenotypes between intraepithelial and stromal lymphocytes in early-stage tongue cancer. Cancer Res 2016;67:11195-201.

185. Pace E, Di Sano C, Ferraro M, et al. Altered CD94/ NKG2A and perforin expression reduce the cytotoxic activity in malignant pleural effusions. Eur J Cancer 2011;47:296-304.

186. Gillard-Bocquet M, Caer C, Cagnard N, et al. Lung tumor microenvironment induces specific gene expression signature in intratumoral NK cells. Front Immunol 2013;4:19.

187.Jin S, Deng Y, Hao JW, et al. NK cell phenotypic modulation in lung cancer environment. PLoS One 2014;9:e109976.

188. Chang WC, Li CH, Chu LH, et al. Regulatory T cells suppress natural killer cell immunity in patients with human cervical carcinoma. Int J Gynecol Cancer 2016;26:156-62.

189. Cariani E, Pilli M, Barili V, et al. Natural killer cells phenotypic characterization as an outcome predictor of HCV-linked HCC after curative treatments. Oncoimmunology 2016;5:e1154249.

190. Rocca YS, Roberti MP, Juliá EP, et al. Phenotypic and functional dysregulated blood NK cells in colorectal cancer patients can be activated by cetuximab plus IL-2 or IL-15. Front Immunol 2016;7:413.

191. Ruggeri L, Urbani E, André P, et al. Effects of antiNKG2A antibody administration on leukemia and normal hematopoietic cells. Haematologica 2016;101:626-33.

192. Cifaldi L, Romania P, Falco M, et al. ERAP1 regulates natural killer cell function by controlling the engagement of inhibitory receptors. Cancer Res 2015;75:824-34.

193. Manser AR, Weinhold S, Uhrberg M. Human KIR repertoires: shaped by genetic diversity and evolution. Immunol Rev 2015;267:178-96.

194. Tu MM, Mahmoud AB, Wight A, et al. Ly49 family receptors are required for cancer immunosurveillance mediated by natural killer cells. Cancer Res 
2014;74:3684-94.

195.Tu MM, Mahmoud AB, Makrigiannis AP. Licensed and Unlicensed NK cells: differential roles in cancer and viral control. Front Immunol 2016;7:166.

196. Kulkarni S, Martin MP, Carrington M. The Yin and Yang of HLA and KIR in human disease. Semin Immunol 2008;20:343-52.

197. Romagné F, André P, Spee P, et al. Preclinical characterization of 1-7F9, a novel human anti-KIR receptor therapeutic antibody that augments natural killermediated killing of tumor cells. Blood 2009;114:2667-77.

198. Carlsten M, Korde N, Kotecha R, et al. Checkpoint Inhibition of KIR2D with the monoclonal antibody IPH2101 induces contraction and hyporesponsiveness of NK cells in patients with myeloma. Clin Cancer Res 2016;22:5211-22.

199. Ardolino M, Azimi CS, Iannello A, et al. Cytokine therapy reverses NK cell anergy in $\mathrm{MHC}$-deficient tumors. J Clin Invest 2014;124:4781-94.

200.Benson DM, Cohen AD, Jagannath S, et al. A Phase I Trial of the Anti-KIR Antibody IPH2101 and lenalidomide in patients with relapsed/refractory multiple myeloma. Clin Cancer Res 2015;21:4055-61.

201. Nijhof IS, Lammerts van Bueren JJ, van Kessel B, et al. Daratumumab-mediated lysis of primary multiple myeloma cells is enhanced in combination with the human anti-KIR antibody IPH2102 and lenalidomide. Haematologica 2015;100:263-8.

202.Pesce S, Greppi M, Tabellini G, et al. Identification of a subset of human natural killer cells expressing high levels of programmed death 1: A phenotypic and functional characterization. J Allergy Clin Immunol 2017;139:33546.e3.

203.Beldi-Ferchiou A, Lambert M, Dogniaux S, et al. PD-1 mediates functional exhaustion of activated NK cells in patients with Kaposi sarcoma. Oncotarget 2016;7:72961-77.

204. Benson DM, Bakan CE, Mishra A, et al. The PD-1/PD$\mathrm{L} 1$ axis modulates the natural killer cell versus multiple myeloma effect: a therapeutic target for CT-011, a novel monoclonal anti-PD-1 antibody. Blood 2010;116:2286-94.

205. Bottino C, Castriconi R, Pende D, et al. Identification of PVR (CD155) and Nectin-2 (CD112) as cell surface ligands for the human DNAM-1 (CD226) activating molecule. J Exp Med 2003;198:557-67.

206.Iguchi-Manaka A, Kai H, Yamashita Y, et al. Accelerated tumor growth in mice deficient in DNAM-1 receptor. J Exp Med 2008;205:2959-64.

207. Bernhardt G. TACTILE becomes tangible: CD96 discloses its inhibitory peculiarities. Nat Immunol 2014;15:406-8.

208. Chan CJ, Martinet L, Gilfillan S, et al. The receptors CD96 and CD226 oppose each other in the regulation of natural killer cell functions. Nat Immunol 2014;15:431-8.

209. Blake SJ, Stannard K, Liu J, et al. Suppression of metastases using a new lymphocyte checkpoint target for cancer immunotherapy. Cancer Discov 2016;6:446-59.
Cite this article as: Donini C, D'Ambrosio L, Grignani G, Aglietta M, Sangiolo D. Next generation immune-checkpoints for cancer therapy. J Thorac Dis 2018;10(Suppl 13):S1581S1601. doi: 10.21037/jtd.2018.02.79 